\title{
MAASTRICHTIAN-EARLY DANIAN RADIOLARIANS AND OSTRACODES FROM ODP SITE 1001B, CARIBBEAN SEA
}

\author{
GUSTAVO NUNES AUMOND, KARLOS GUILHERME DIEMER KOCHHANN, LEONARDO \\ SANTOS FLORISBAL, SIMONE BAECKER FAUTH, CRISTIANINI TRESCASTRO BERGUE \\ \& GERSON FAUTH
}

\author{
Laboratório de Micropaleontologia, UNISINOS, Av. Unisinos, 950, 93022-000, São Leopoldo, RS, Brasil. \\ gustavo.aumond@terra.com.br,k.kochhann@gmail.com,florisba@yahoo.com.br, sbfauth@unisinos.br, \\ cbergue@unisinos.br, gersonf@unisinos.br
}

\begin{abstract}
The ODP, Site 1001B (Leg 165), located in the Caribbean Sea, presents a well preserved sedimentary succession ranging from the Cretaceous to the Neogene that consists predominantly of pelagic limestone. The main objective of this article is to study taxonomically the Maastrichtian radiolarian and the Maastrichtian-early Danian ostracode faunas recovered in the studied site and to compare them to faunas previously described elsewhere. Despite the discontinuity of the occurrences and the scarcity of specimens, 45 radiolarian species and seven ostracode species assigned to six genera, were identified. The radiolarians were recovered only in the cores $21 \mathrm{R}$ and $20 \mathrm{R}$ and correspond to a typical Upper Cretaceous fauna, containing even species considered as index fossils such as Orbiculiforma renillaeformis (Campbell \& Clark) Pessagno. The seven ostracode taxa occur in the Maastrichtian-early Danian interval. The single specimen of Paleoabyssocythere sp. here recorded could not be ascribed to none of the described species and possibly constitutes a new taxon. The presence of the ostracode association Paleoabyssocythere-Krithe-Bairdoppilata-Cytherella suggests deposition in a bathyal or outer shelf environment.
\end{abstract}

Key words: radiolarians, ostracodes, Cretaceous, Paleogene, ODP Site 1001B, Caribbean Sea.

RESUMO - O ODP Site 1001B (Leg 165), localizado no mar do Caribe, apresenta uma sucessão sedimentar bem preservada que abrange do Cretáceo ao Neógeno e é composta predominantemente por carbonatos pelágicos. O principal objetivo do presente artigo é descrever taxonomicamente a fauna de radiolários do Maastrichtiano e a fauna de ostracodes do intervalo Maastrichtiano-Eodaniano recuperadas no Site 1001B, comparando-as com faunas previamente descritas. Apesar da escassez de ocorrências e de espécimes, foram identificados seis gêneros de ostracodes, subdivididos em sete espécies, e 45 espécies de radiolários. Radiolários foram recuperados nos testemunhos 21R e 20R e correspondem a uma fauna típica do Cretáceo Superior, apresentando espécies cosideradas fósseis guias, como Orbiculiforma renillaeformis (Campbell \& Clark) Pessagno. Os sete táxons de ostracodes ocorrem no intervalo Maastrichtiano-Eodaniano. O único espécime de Paleoabyssocythere sp. registrado não pode ser atribuído a nenhuma das espécies já descritas, possivelmente constituindo um novo táxon. A presença da associação de ostracodes Paleoabyssocythere-Krithe-Bairdoppilata-Cytherella sugere deposição em um ambiente batial ou de plataforma externa.

Palavras-chave: radiolários, ostracodes, Cretáceo, Paleógeno, ODP Site 1001B, mar do Caribe.

\section{INTRODUCTION}

Stratigraphic successions containing the record of the Cretaceous/Paleogene $(\mathrm{K} / \mathrm{Pg})$ transition are rare and of great significance to the scientific community (MacLeod et al., 1997). The Caribbean carbonated shelf contains one of the most important of these records, being closely related to the Yucatán Peninsula, where at $65 \mathrm{Myr}$ ago a possible meteoric collision began one of the greatest mass extinctions in the history of the Earth (Ridley, 1996).

The main objective of the present work is to study the radiolarian and ostracode faunas recovered in the Maastrichtian-early Danian interval of the ODP (Ocean Drilling Program) Site 1001B, contributing to the improvement of the knowledge about these groups in this time interval.

\section{STUDY AREA}

The samples analyzed in the present study comprise the Maastrichtian-early Danian interval of the ODP Leg 165, Site 1001B (1545.418' N/74º54.626' W), cores 21R-16R (Figure 1). This interval possesses a precise biostratigraphic control 
based on nannofossils and planktonic foraminifers (Sigurdsson et al., 1997; Figure 2).

The tectonic reconstruction proposed to explain the origin of the Caribbean oceanic crust, encloses a crustal spreading zone localized at the Pacific Ocean (Burke, 1988; Donnelly et al., 1990; Pindell \& Barrett, 1990). These authors suggest that an intense volcanism associated to the Galápagos hot spot, had generated the Caribbean Oceanic Plateau, as well as, the Farallon Plate. Two stratigraphic sequences are recognized in the studied area (Sigurdsson et al., 1997). The first sequence directly overlaid on the volcanic basement, which depositional period ranges from the Middle Campanian to the Middle Eocene, is predominantly composed by chalk and limestone interstratified with a minor amount of mudstone and siltstone. With the sea level fall, which occurred in the Eocene, an erosive boundary was generated, followed by the deposition of the second stratigraphic sequence, which is composed of pelagic ooze, and follows up from the middle Miocene to the Pleistocene.

\section{MATERIAL AND METHODS}

Lithologically the samples are composed dominantly by pelagic limestone interstratified with small proportion of mudstone and siltstone. Foraminifers are very abundant throughout the hole, whereas radiolarians and ostracodes only occur in some samples.

The samples were immersed in $40 \%$ hydrogen peroxide solution $\left(\mathrm{H}_{2} \mathrm{O}_{2}\right)$ during 72 hours and later washed and fractionated in four meshes $(45,63,180$ and $250 \mu \mathrm{m})$, in order to recover both radiolarians and ostracodes. Finally, specimens were hand-picked under stereo-microscope. Representative radiolarians and ostracodes were photographed in Scanning Electron Microscope (SEM) at the CENPES/ PETROBRAS and at the Centro de Microscopia e Microanálises (CEMM) of Pontifícia Universidade Católica do Rio Grande do
Sul (PUCRS). Radiolarians were also photographed under optical microscopy with the use of a Zeiss Axioscope 40.

In the two radiolarian-rich samples (1001B/21R/6W/71-75 $\mathrm{cm}$ and $1001 \mathrm{~B} / 20 \mathrm{R} / 5 \mathrm{~W} / 69-73 \mathrm{~cm}) 300$ specimens were picked. In the sample $21 \mathrm{R} / 6 \mathrm{~W}$ only specimens retained in the $63 \mu \mathrm{m}$ mesh were recovered.

The specimens studied in the present work will be hold in the collections of Museu de Paleontologia, Universidade do Vale do Rio dos Sinos (UNISINOS), Brazil under the curatorial number ULVG-7011 to ULVG-7062. In the ostracode section of the systematic study the following abbreviations are used: $\mathbf{l}$, length; h, height; w, width; $\mathbf{C}$, carapace; RV, right valve; $\mathbf{L V}$, left valve.

\section{SYSTEMATIC PALEONTOLOGY}

\section{Radiolarians}

Order NASSELLARIA Ehrenberg, 1875 Family ARCHAEODICTYOMITRIDAE Pessagno, 1976 Genus Dictyomitra Zittel, 1876 emend. Pessagno, 1976 Dictyomitra napaensis Pessagno, 1976

(Figure 3A)

Dictyomitra napaensis Pessagno, 1976, p. 53, pl. 4, fig. 16; pl. 5, fig. 1.

Dictyomitra napaensis Pessagno. Pessagno, 1977a, p. 942, pl. 3, fig. 1.

Dictyomitra napaensis Pessagno. Musavu-Moussavou \& Danelian, 2006, p. 151, pl. 1, figs. 8-10.

Figured specimen. ULVG-7018.

Occurrence. Middle-upper Turonian to Upper Coniacian of Great Valley Sequence, California (Pessagno, 1976, 1977a); upper Cenomanian from ODP sites 1258 and 1261, Leg 207, Demerara Rise (Musavu-Moussavou \& Danelian, 2006). Material. 30 specimens; sample 1001B/21R/6W/71-75 cm.

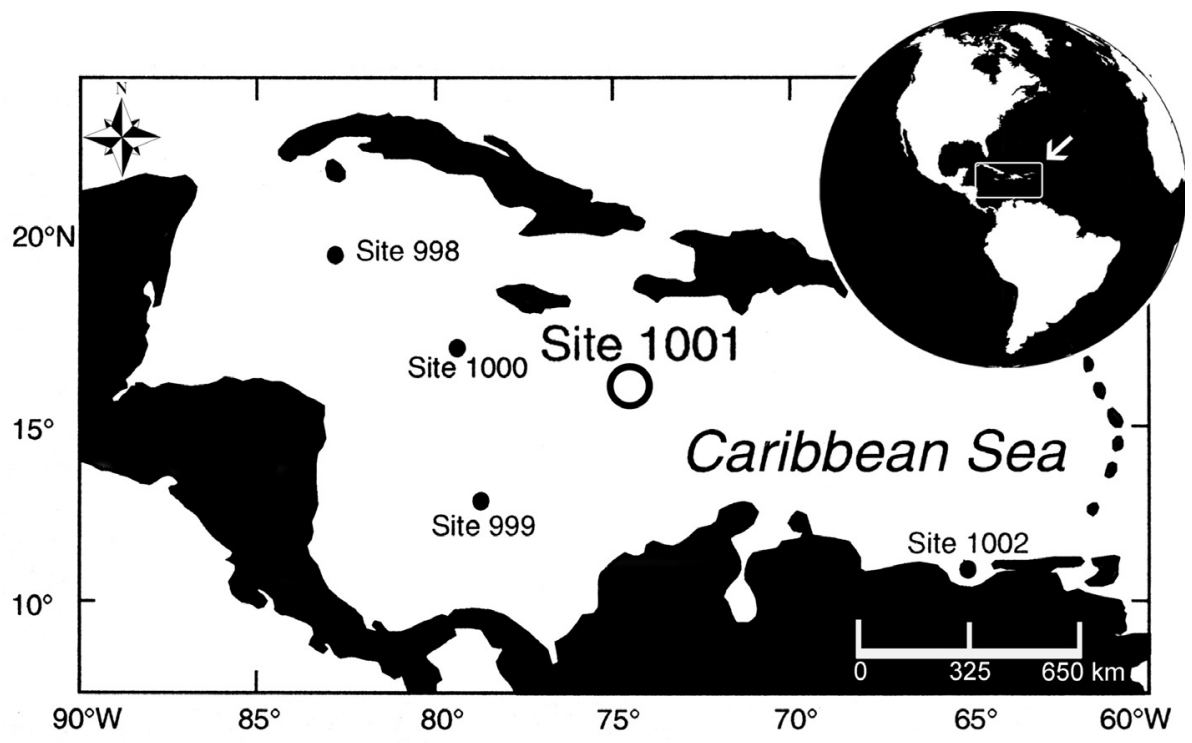

Figure 1. Location of the ODP Site 1001B at the Caribbean Sea. 


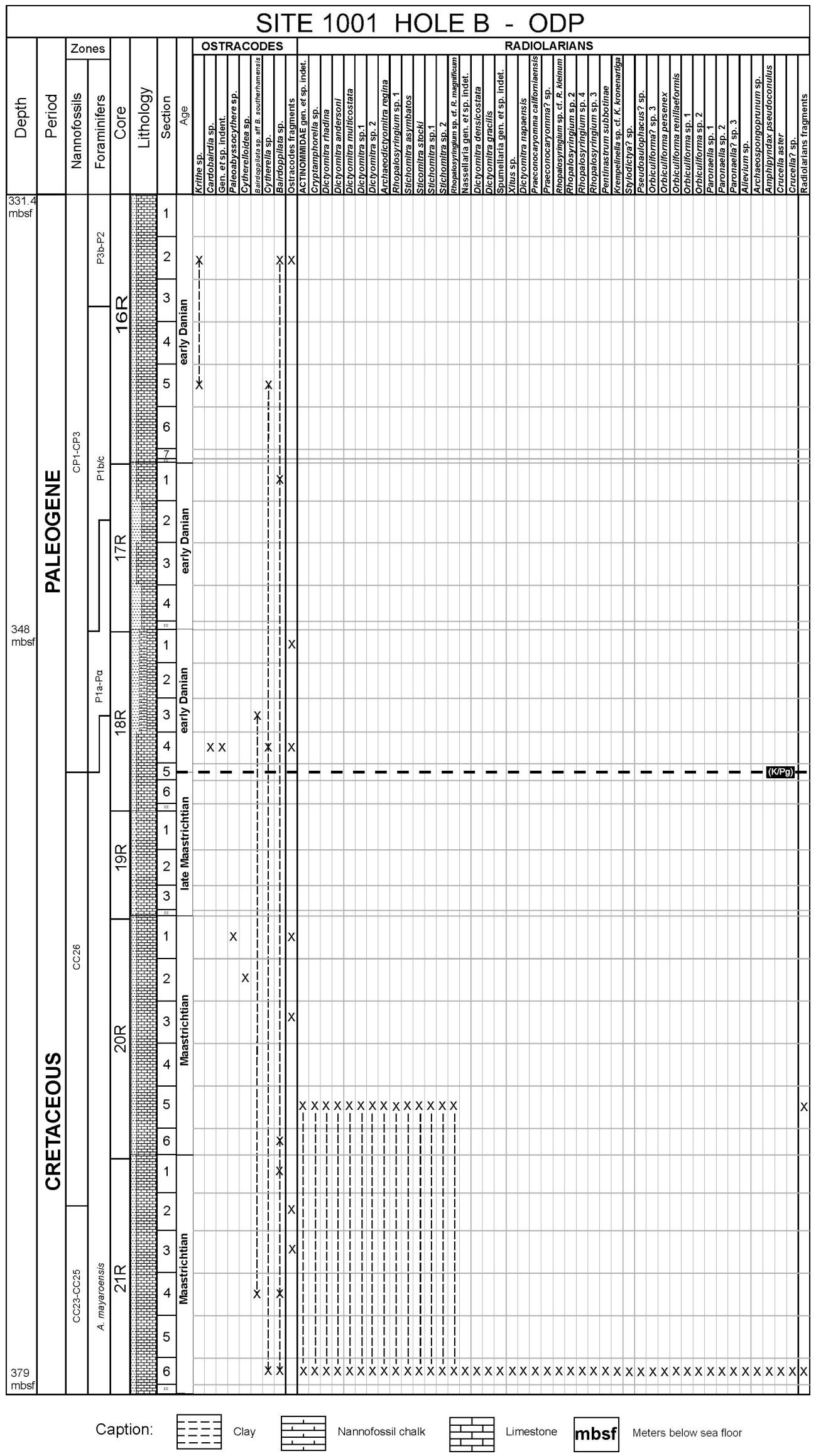

Figure 2. Ostracode and radiolarian occurrences in the studied samples from site 1001B (modified from Sigurdsson et al., 1997). 
Dictyomitra rhadina Foreman, 1968

(Figure 3F)

Dictyomitra rhadina Foreman, 1968, p. 66, pl. 7, figs. 5a,b. Dictyomitra rhadina Foreman. Hollis, 1997, p. 69, pl. 16, figs. 17-20.

Figured specimen. ULVG-7019.

Occurrence. Upper Maastrichtian of California (Foreman, 1968); Maastrichtian to lower Paleocene of New Zealand (Hollis, 1997); upper Cretaceous to lower Paleocene from DSDP site 208, New Zealand (Hollis, 2002).

Material. 15 specimens; samples 1001B/21R/6W/71-75 cm and $1001 \mathrm{~B} / 20 \mathrm{R} / 5 \mathrm{~W} / 69-73 \mathrm{~cm}$.

Dictyomitra andersoni (Campbell \& Clark) Foreman, 1968 (Figure 3E)

Dictyomitra andersoni (Campbell \& Clark) Foreman. Foreman, 1968, p. 68, pl. 7, figs. 6a,b.

Dictyomitra andersoni (Campbell \& Clark) Foreman. Hollis, 1997, p. 69, pl. 16, figs. 11-16.

Figured specimen. ULVG-7020.

Occurrence. Upper Maastrichtian of California (Foreman, 1968); Campanian of Cyprus Island (Urquhart, 1994); Campanian-Maastrichtian to late Paleocene of New Zealand (Hollis, 1997; Hollis \& Strong, 2003); middle Paleocene from ODP Site 1121 and Upper Cretaceous to Paleocene from DSDP Site 208, New Zealand (Hollis, 2002).

Material. 24 specimens; samples 1001B/21R/6W/71-75 cm and $1001 \mathrm{~B} / 20 \mathrm{R} / 5 \mathrm{~W} / 69-73 \mathrm{~cm}$.

Dictyomitra multicostata Zittel, 1876 emend. Pessagno, 1976

(Figure 3D)

Dictyomitra multicostata Zittel. Pessagno, 1963, p. 206, pl. 1, fig. 10; pl. 4, figs. 1,3; pl. 5, fig. 7 .

Dictyomitra multicostata Zittel. Foreman, 1968, pl. 7, figs. 4a,b.

Dictyomitra multicostata Zittel. Pessagno, 1976, p. 52, pl. 14, figs. 4-9.

Dictyomitra multicostata Zittel. O’Dogherty, 1994, p. 82, pl. 4, figs. 17-18.

Dictyomitra multicostata Zittel. Hollis, 1997, p. 69, pl. 16, figs. 6-10.

Dictyomitra multicostata Zittel. Packer \& Hart, 2005, p. 142, figs. 6o,p.

Figured specimen. ULVG-7021.

Occurrence. Upper Maastrichtian of California (Foreman, 1968); lower Turonian of Italy and Spain (O’Dogherty, 1994); Campanian of Cyprus Island (Urquhart, 1994); Maastrichtian to lower Paleocene of New Zealand (Hollis, 1997); lower Campanian of Puerto Rico (Pessagno, 1963); middle Campanian to Maastrichtian of Great Valley Sequence, California (Pessagno, 1976); Upper Cretaceous to middle Paleocene from DSDP site 208, New Zealand (Hollis, 2002); Santonian-Campanian of Kara Crater, Russia (Vishnevskaya
\& Alekseev, 2008); Coniacian-Santonian of Bornholm, Denmark (Packer \& Hart, 2005); Coniacian-Turonian of Russia (Vishnevskaya et al., 2006); Campanian of Russia (Olfer'ev et al., 2007).

Material. 110 specimens; samples 1001B/21R/6W/71-75 cm and $1001 \mathrm{~B} / 20 \mathrm{R} / 5 \mathrm{~W} / 69-73 \mathrm{~cm}$.

\section{Dictyomitra densicostata Pessagno, 1976}

(Figure 4O)

Dictyomitra densicostata Pessagno, 1975, p. 1017, pl. 5, figs. 1-3.

Dictyomitra densicostata Pessagno. Pessagno, 1976, p. 51, pl. 14, figs. 10-14, 16.

Dictyomitra densicostata Pessagno. Pessagno, 1977a, p. 947, pl. 8, figs. 3,4 .

Dictyomitra densicostata Pessagno. Vishnevskaya \& Alekseev, 2008, p. 1367, figs. 3j-1.

Dictyomitra densicostata Pessagno. Olfer'ev et al., 2007, p. 646, pl. 19, fig. 10.

Figured specimen. ULVG-7022.

Occurrence. Upper Coniacian to uppermost Campanian of Great Valley Sequence, California (Pessagno, 1976); Campanian from the DSDP Site 275, New Zealand (Pessagno, 1975); upper Coniacian to Santonian of California (Pessagno, 1977a); Santonian of Russia (Olfer'ev et al., 2007); SantonianCampanian of Kara Crater, Russia (Vishnevskaya \& Aleekseev, 2008).

Material. 1 specimen; sample 1001B/21R/6W/71-75 cm.

$$
\text { Dictyomitra gracilis (Squinabol) O’Dogherty, } 1994
$$

(Figure 3C)

Dictyomitra gracilis (Squinabol, 1903b). O’Dogherty, 1994, p. 73, pl. 1, figs. 12-25.

Mita gracilis (Squinabol) Taketani. Urquhart, 1994, p. 1406 , figs. 5(8, 14).

Figured specimen. ULVG-7023.

Occurrence. Campanian of Cyprus Island (Urquhart, 1994); upper Albian of Italy and Spain (O’Dogherty, 1994).

Material. 5 specimens; sample 1001B/21R/6W/71-75 cm.

\section{Dictyomitra sp. 1}

(Figure 3B)

\section{Figured specimen. ULVG-7024}

Description. Multi-segmented skeleton (10 to 13 segments) with elongated, conical to cylindrical-shaped test, and with well developed longitudinally aligned costae through all surface. Cephalis slightly acute apically with a small apical protrusion. Costae obscured at strictures. A single parallel row of aligned sub-circular pores lies between adjacent costae. Deep and well-developed constrictions occurring at joints between segments formed by two transverse rows of pores, which are followed by the costae outline. Lateral outlines of the test strongly lobate at segmental division levels. Chambers gradually increase in length and width, 
becoming cylindrical distally, where one or two segments with pores bigger than the ones from the proximal segments occur, and costae became more irregular.

Remarks. This species differs from Dictyomitra cf. crassispina figured by Foreman (1968) by the two rows of pores at strictures. It can not be included in the genus Pseudodictyomitra due to the continuous costae obscured at strictures.

Material. 13 specimens; samples 1001B/21R/6W/71-75 cm and $1001 \mathrm{~B} / 20 \mathrm{R} / 5 \mathrm{~W} / 69-73 \mathrm{~cm}$.

\section{Dictyomitra sp. 2}

(Figure 3G)

Figured specimen. ULVG-7025.

Description. Multi-segmented form (six to eight segments) with test elongate and conical shape, with well developed vertically aligned costae obscured on cephalis and thorax. Cephalis slightly acute apically. Between adjacent costae, single parallel row of aligned sub-circular pores. Deep and well-developed constrictions occurring at joints of the segments, formed by one or two transverse rows of pores, which are followed by the costae outline. Costae are normally obscured at strictures. One transverse row of large circular depressions that may perforate the shell wall as pores is present on the central part of each abdominal segment between adjacent costae. Lateral outlines of the test strongly lobate at segmental division levels. Chambers gradually increase in length and width distally. Distal segment with distal margin ragged, may or may not possesses small costal projections.

Remarks. Differs from all the other species of Dictyomitra recovered in the studied material by possessing deep constrictions at the joints of the segments, formed probably by two transverse rows of pores, and by its evident conical shape. Another significant difference is the presence of a transverse row of large circular depressions that may perforate the shell wall as pores at the central part of each abdominal segment between adjacent costae.

Material. 32 specimens; samples 1001B/21R/6W/71-75 cm and $1001 \mathrm{~B} / 20 \mathrm{R} / 5 \mathrm{~W} / 69-73 \mathrm{~cm}$.

Genus Archaeodictyomitra Pessagno, 1976 Archaeodictyomitra regina (Campbell \& Clark) Pessagno, 1976

(Figure 4P)

Dictyomitra regina (Campbell \& Clark). Foreman, 1968, p. 68-79, pl. 8, figs. 5a-c.

Figured specimen. ULVG-7026.

Occurrence. Upper Campanian to Maastrichtian of Great Valley Sequence, California (Pessagno, 1976); upper Maastrichtian of California (Foreman, 1968).

Material. 6 specimens; samples 1001B/21R/6W/71-75 cm and $1001 \mathrm{~B} / 20 \mathrm{R} / 5 \mathrm{~W} / 69-73 \mathrm{~cm}$.
Family AMPHIPYNDACIDAE Riedel, 1967

Amphipyndax Foreman emend. Sanfilippo \& Riedel, 1985

Amphipyndax pseudoconulus (Pessagno) Empson-

Morin, 1982

(Figure 3N)

Lithostrobus (Lithostrobus) pseudoconulus Pessagno, 1963 p. 210, pl. 1, fig. 8; pl. 5, figs. 6,8 .

Amphipyndax pseudoconulus (Pessagno). Sanfilippo \& Riedel, 1985, p. 596, fig. 7(1a-c).

Figured specimen. ULVG-7027.

Occurrence. Lower Campanian of Puerto Rico (Pessagno, 1963); Campanian of Cyprus Island (Urquhart, 1994).

Material. 28 specimens; sample 1001B/21R/6W/71-75 cm.

\author{
Family XITIDAE Pessagno, 1977b \\ Genus Xitus Pessagno, 1977b \\ Xitus sp. \\ (Figure 3H)
}

Figured specimen. ULVG-7028.

Description. Multi-segmented conical skeleton (six to eight segments) with imperforated cephalis and with or without apical spine. All segments present small subcircular pores, except by the cephalis. Circumferential ridges, composed by nodes and interconnected by bars, are present mainly at segmental divisions.

Remarks. Differs from Stichomitra asymbatos by the denser arrangement of the circumferential ridges, conspicuously developed at segmental divisions.

Material. 9 specimens; sample 1001B/21R/6W/71-75 cm.

Family EUCYRTIDIIDAE Ehremberg, 1847

Genus Stichomitra Cayeux 1897

Stichomitra stocki (Campbell \& Clark) O’Dogherty, 1994

(Figure 3K)

Amphipyndax stocki (Campbell \& Clark) Foreman, 1968, p. 78, pl. 8, figs. $12 \mathrm{a}-\mathrm{c}$.

Amphipyndax stocki (Campbell \& Clark) Foreman. Pessagno, 1975, p. 1016, pl. 4, figs. 4-8.

Stichomitra stocki (Campbell \& Clark) Foreman. O’Dogherty, 1994, p. 147, pl. 18, figs. 9-15.

Amphipyndax stocki (Campbell \& Clark) gr., new group. Hollis, 1997, p. 66, pl. 15, figs. 5-11.

Stichomitra sp. cf. Amphipyndax stocki Packer \& Hart, 2005, p. 142 , fig. $6 \mathrm{e}$.

Figured specimen. ULVG-7029.

Occurrence. Upper Maastrichtian of California (Foreman, 1968); lower Turonian and upper Cenomanian of Italy and Spain (O'Dogherty, 1994); Campanian of Cyprus Island (Urquhart, 1994); Campanian-Maastrichtian to lower Eocene of New Zealand (Hollis, 1997; Hollis \& Strong, 2003); latest Campanian to Maastrichtian from DSDP Site 275, New Zealand coast (Pessagno, 1975); Upper Cretaceous to Paleocene from the ODP site 1121 and DSDP site 208, New Zealand (Hollis, 2002); Coniacian-Santonian of Bornholm, 
Denmark (Packer \& Hart, 2005); Campanian of Russia (Olfer'ev et al., 2007); Coniacian-Turonian of Russia (Vishnevskaya et al., 2006); Santonian-Campanian of the Russian Pacific Margin (Vishnevskaya \& Basov, 2007).

Material. 5 specimens; samples 1001B/21R/6W/71-75 cm and $1001 \mathrm{~B} / 20 \mathrm{R} / 5 \mathrm{~W} / 69-73 \mathrm{~cm}$.

Stichomitra asymbatos Foreman, 1968

(Figures 3I, J)

Figured specimen. ULVG-7030.

Occurrence. Upper Maastrichtian of California (Foreman, 1968); Campanian of Russia (Olfer'ev et al., 2007); ConiacianTuronian of Russia (Vishnevskaya et al., 2006).

Material. 21 specimens; samples 1001B/21R/6W/71-75 cm and $1001 \mathrm{~B} / 20 \mathrm{R} / 5 \mathrm{~W} / 69-73 \mathrm{~cm}$.

\section{Stichomitra sp.1}

(Figure 3L)

Figured specimen. ULVG-7031.

Description. Multi-segmented form. Cephalis is short, lacking apical horn, and poreless. Well developed strictures, generating a lobate outline; pores of the thorax and subsequent segments arranged in a square pattern or irregularly in only one shell layer.

Remarks. This species differs from all other species from the genus Stichomitra recovered in the studied material by its strong lobate outline.

Material. 19 specimens; samples 1001B/21R/6W/71-75 cm and $1001 \mathrm{~B} / 20 \mathrm{R} / 5 \mathrm{~W} / 69-73 \mathrm{~cm}$.

\section{Stichomitra sp. 2}

(Figure 3M)

Figured specimen. ULVG-7032.

Description. Test slender, conical to subcylindrical distally. Cephalis is small and imperforate. Polygonal pores of the thorax and subsequent segments quincuncially arranged.

Remarks. Differs from all other species of Stichomitra by the predominantly conical outline and large polygonal quincuncially arranged pore frames.

Material. 21 specimens; samples 1001B/21R/6W/71-75 cm and $1001 \mathrm{~B} / 20 \mathrm{R} / 5 \mathrm{~W} / 69-73 \mathrm{~cm}$.

Family CANNOBOTRYIDAE Haeckel, 1881

Genus Rhopalosyringium Campbell \& Clark, 1944

Rhopalosyringium cf. R. kleinum Empson-Morin, 1981

(Figure 30)

cf. Rhopalosyringium kleinum Empson-Morin, 1981, p. 265, pl. 8, figs. 2, 3 .

Figured specimen. ULVG-7033.

Occurrence. Campanian from DSDP Site 313, Mid-Pacific Mountain (Empson-Morin, 1981).

Material. 7 specimens; sample 1001B/21R/6W/71-75 cm.
Rhopalosyringium cf. R. magnificum Campbell \& Clark, 1944

(Figure 3Q)

cf. Rhopalosyringium magnificum Campbell \& Clark, 1944, p. 30, pl. 7, figs. 16, 17.

cf. Rhopalosyringium cf. magnificum Empson-Morin, 1981, p. 265, pl. 8, figs. 1a-d.

Figured specimen. ULVG-7034.

Occurrence. Campanian from DSDP Site 313, Mid-Pacific Mountains (Empson-Morin, 1981); Upper Cretaceous of California (Campbell \& Clark, 1944).

Material. 12 specimens; samples 1001B/21R/6W/71-75 cm and $1001 \mathrm{~B} / 20 \mathrm{R} / 5 \mathrm{~W} / 69-73 \mathrm{~cm}$.

Rhopalosyringium sp. 1

(Figure 3P)

Figured specimen. ULVG-7035.

Description. Test composed of three segments (including the tube). Cephalis small and hemispherical, with small pores that develop small nodes at the bars junctions of the pore frames. Thorax subspherical with large hexagonal to pentagonal pore frames. Test terminates in an open tube which has smaller pores than the thorax, and nodes irregularly distributed. The terminal tube may increase in width distally. Remarks. This species possesses very poor-developed strictures and, differs from all other species of Rhopalosyringium recovered in this material by its terminal tube which may increases in width distally.

Material. 2 specimens; samples 1001B/21R/6W/71-75 cm and $1001 \mathrm{~B} / 20 \mathrm{R} / 5 \mathrm{~W} / 69-73 \mathrm{~cm}$.

Rhopalosyringium sp. 2

(Figure 3S)

Figured specimen. ULVG-7036.

Description. Test of three segments with strictures relatively diffuses in comparison to the other species of Rhopalosyringium. Cephalis small and hemispherical, bearing an apical horn, with small pores developing small nodes at the bars junctions of the pore frames. Thorax subspherical with large pentagonal and hexagonal pore frames arranged quincuncially. Test terminates in an open tube which presents pores and nodes slightly developed and irregularly distributed. Terminal tube decreases in width distally.

Remarks. This species presents the proximal part of test conical, and the distal portion (terminal tube) inversely conical in outline.

Material. 2 specimens; sample 1001B/21R/6W/71-75 cm.

Rhopalosyringium sp. 3

(Figure 3T)

Figured specimen. ULVG-7037.

Description. Test composed of cephalis, thorax and terminal tube. Cephalis is small, hemispherical, with small irregularly 
distributed pores. Cephalis can develop an apical horn in well preserved specimens. Thorax subspherical with polygonal pore frames. Distal segment (portion of the test) inversely conical, open and bearing circular pores.

Remarks. Differs from Rhopalosyringium sp. 1 by having an inversely conical distal segment, and by the absence of well-developed strictures.

Material. 3 specimens; sample 1001B/21R/6W/71-75 cm.

Rhopalosyringium sp. 4

(Figure 3R)

Figured specimen. ULVG-7038.

Description. Skeleton composed by two segments. Cephalis hemispherical, bearing an acute small apical horn. Collar stricture diffuse. Thorax subspherical, with hexagonal poreframes presenting small nodes at the bars junctions.

Remarks. In lateral view, under stereo-microscope, this species presents the distal margin ragged.

Material. 6 specimens; sample 1001B/21R/6W/71-75 cm.

Genus Krempelinella Empson-Morin, 1981

Krempelinella cf. K. kronenartiga Empson-Morin, 1981

(Figure 4Q)

cf. Krempelinella kronenartiga Empson-Morin, 1981, p. 265, pl. 8, figs. 4-7d; pl. 9, figs 1a-d.

Figured specimen. ULVG-7039

Occurrence. Campanian from DSDP Site 313, Mid-Pacific Mountains (Empson-Morin, 1981).

Material. 2 specimens; sample 1001B/21R/6W/71-75 cm.

Family WILLIRIEDELLIDAE Dumitrica, 1970

Genus Cryptamphorella Dumitrica, 1970

Cryptamphorella sp.

(Figure 3U)

Figured specimen. ULVG-7040.

Description. Cryptothoracic nassellarian, tri-chambered, with large spherical abdomen; small cephalo-thoracic portion, poreless or with small pores, and partially depressed in the abdominal cavity. Abdomen spherical with rough surface, and pentagonal and hexagonal pore frames, with bars developing nodes at junctions.

Material. 8 specimens; samples 1001B/21R/6W/71-75 cm and $1001 \mathrm{~B} / 20 \mathrm{R} / 5 \mathrm{~W} / 69-73 \mathrm{~cm}$.

\section{NASSELLARIAINCERTAE SEDIS \\ Nassellaria gen. et $\mathrm{sp}$. indet. \\ (Figure 4I)}

Figured specimen. ULVG-7041.

Remarks. Possible cryptocephalic Nassellaria with pores quincuncially arranged.

Material. 4 specimens; sample 1001B/21R/6W/71-75 cm.

\author{
Order SPUMELLARIA Ehrenberg, 1875 \\ Family ACTINOMMIDAE Haeckel 1862 emend. De Wever \\ et al., 2001 \\ ACTINOMMIDAE gen. et $\mathrm{sp}$. indet. \\ (Figure 4M)
}

Figured specimen. ULVG-7042.

Description. Test lenticular without spines. Cortical shell with small hexagonal pore frames.

Material. 19 specimens; samples 1001B/21R/6W/71-75 cm and $1001 \mathrm{~B} / 20 \mathrm{R} / 5 \mathrm{~W} / 69-73 \mathrm{~cm}$.

Family CONOCARYOMMIDAE Lipman, 1969 emend. De

Wever et al., 2001

Genus Praeconocaryomma Pessagno, 1976

Praeconocaryomma californiaensis Pessagno, 1976

(Figure 3W)

Praeconocaryomma californiaensis Pessagno, 1976, p. 41, pl. 7, figs. 1-8.

Praeconocaryomma californiaensis Pessagno. Pessagno, 1977a, p. 942, pl. 3, figs. 3-6.

Praeconocaryomma californiaensis Pessagno. Packer \& Hart, 2005, p. 144, figs. 7j, k.

Praeconocaryomma californiaensis Pessagno. Vishnevskaya \& Aleekseen, 2008, p. 1368, fig. 2f.

Figured specimen. ULVG-7043.

Occurrence. Coniacian of Great Valley Sequence, California (Pessagno, 1976, 1977a); Coniacian-Santonian of Bornholm, Denmark (Packer \& Hart, 2005); Santonian of Russia (Olfer'ev et al., 2007); Santonian-Campanian of Kara Crater, Russia (Vishnevskaya \& Alekseev, 2008).

Material. 10 specimens; sample 1001B/21R/6W/71-75 cm.

Praeconocaryomma? sp.

(Figure 3X)

Figured specimen. ULVG-7044.

Description. Cortical shell presents six large elliptical pores surrounding each (?)mamma; area between (?)mammae with circular to elliptical pores. Central area of (?)mammae have triradiate spines in axial section. Mammary area weakly developed.

Remarks. This species is tentatively assigned to the genus Praeconocaryomma, based on the presence of weakly developed mammary areas.

Material. 10 specimens; sample 1001B/21R/6W/71-75 cm.

Family PSEUDOAULOPHACIDAE Riedel, 1967 emend. De Wever et al., 2001

Genus Alievium Pessagno 1972b

Alievium sp.

(Figure 4G)

Figured specimen. ULVG-7045.

Description. Test sub-triangular in outline; with a meshwork comprised of triangular to subcircular pore frames arranged 


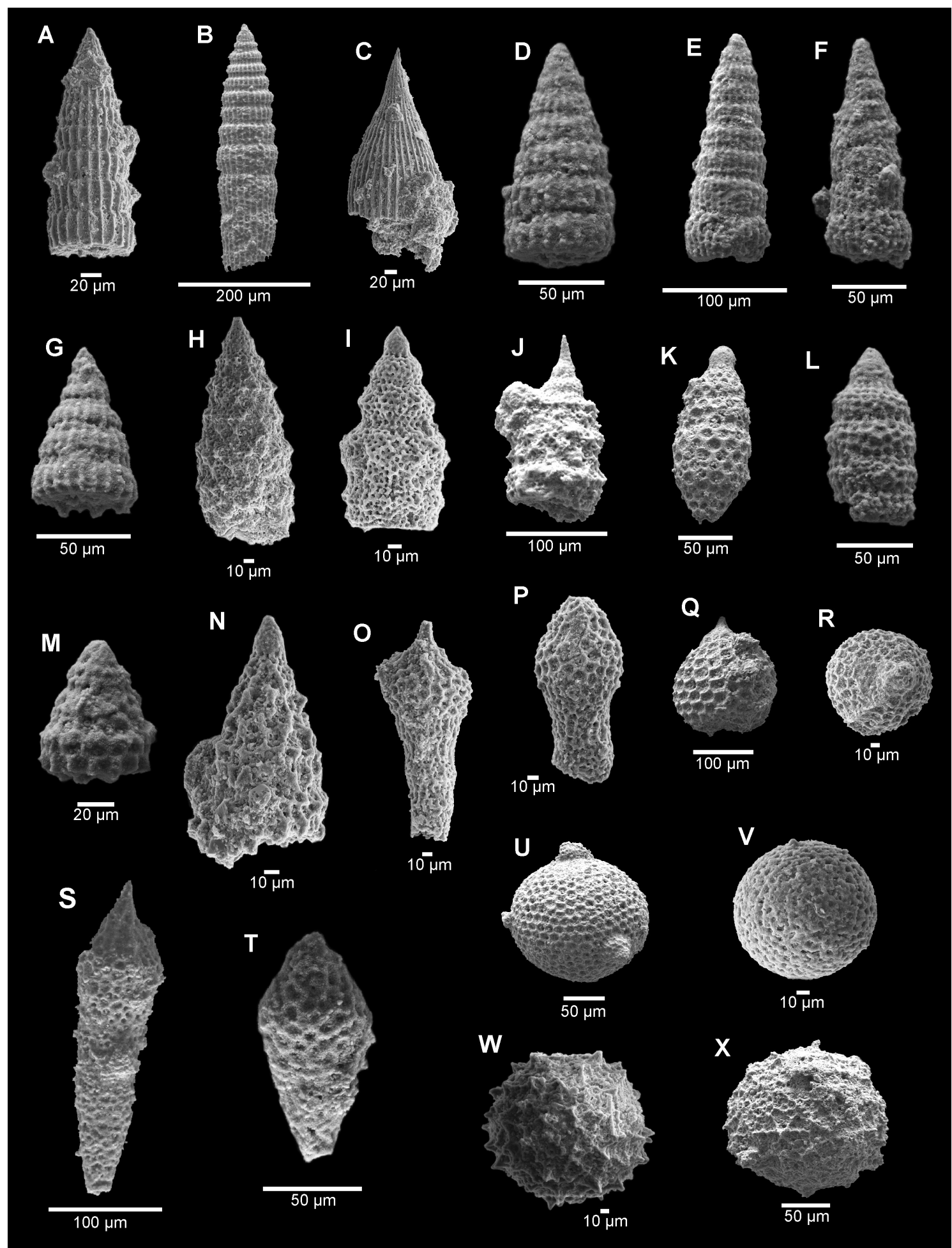

Figure 3. A, Dictyomitra napaensis Pessagno, sample 1001B/21R/6W/71-75 cm. B, Dictyomitra sp. 1, sample 1001B/21R/6W/71-75 cm. C, Dictyomitra gracilis (Squinabol) O'Doguerty, sample 1001B/21R/6W/71-75 cm. D, Dictyomitra multicostata Zittel, sample 1001B/20R/ 5W/69-73 cm. E, Dictyomitra andersoni (Campbell \& Clark) Foreman, sample 1001B/20R/5W/69-73 cm. F, Dictyomitra rhadina Foreman, sample 1001B/20R/5W/69-73 cm. G, Dictyomitra sp. 2, sample 1001B/20R/5W/69-73 cm. H, Xitus sp., sample 1001B/21R/6W/71-75 cm. IJ, Stichomitra asymbatos Foreman, sample 1001B/21R/6W/71-75 cm. K, Sticomitra stocki (Campbell \& Clark) O'Doguerty, sample 1001B/ 21R/6W/71-75 cm. L, Stichomitra sp.1, sample 1001B/20-5W. M, Stichomitra sp. 2, sample 1001B/20R/5W/69-73 cm. N, Amphipyndax pseudoconulus (Pessagno) Empson-Morin, sample 1001B/21R/6W/71-75 cm. O, Rhopalosyringium sp. cf. R. kleinum Empson-Morin, sample 1001B/21R/6W/71-75 cm. P, Rhopalosyringium sp. 1, sample 1001B/21R/6W/71-75 cm. Q, Rhopalosyringium sp. cf. R. magnificum Campbell \& Clark, sample 1001B/21R/6W/71-75 cm. R, Rhopalosyringium sp. 4 (apical view), sample 1001B/21R/6W/71-75 cm. S, Rhopalosyringium sp. 2, sample 1001B/21R/6W/71-75 cm. T, Rhopalosyringium sp. 3, sample 1001B/21R/6W/71-75 cm. U, Cryptamphorella sp., sample 1001B/21R/6W/71-75 cm. V, Spumellaria gen. et sp. indet., sample 1001B/21R/6W/71-75 cm. W, Praeconocaryomma californiaensis Pessagno, sample 1001B/21R/6W/71-75 cm. X, Praeconocaryomma? sp., sample 1001B/21R/6W/71-75 cm. 
in all the surface, developing small nodes at pore-frame bars junctions. Three primary spines occur in the corners of the sub-triangular test, which are apparently tri-radiated in crosssection.

Remarks. No specific determination is possible (all specimens recovered are broken).

Material. 9 specimens; sample 1001B/21R/6W/71-75 cm.

\author{
Genus Pseudoaulophacus Pessagno, 1963 emend. \\ Pessagno 1972b \\ Pseudoaulophacus? sp. \\ (Figure 4F)
}

Figured specimen. ULVG-7046.

Description. Test circular in outline, with larger pores in the elevated central area than those of remainder test; central area poorly elevated. Large conical spines developed in the equatorial plane of the test.

Remarks: The knob-like area showed in the illustration is composed by sedimentary material, and was removed using ultrasound treatment.

Material. 1 specimen; sample 1001B/21R/6W/71-75 cm.

Family ANGULOBRACCHIIDAE Baumgartner, 1980 emend. De Wever et al., 2001

Genus Paronaella Pessagno, 1971

Paronaella sp. 1

(Figure 4A)

Figured specimen. ULVG-7047.

Description. Three-rayed test without bracchiopyle. Rays possess different lengths. Pores shape obscured by the poor preservation. Rays smooth without spines at extremities.

Remarks. Differs from Paronaella? sp. 3 by the presence of rays with practically the same width along their extension.

Material. 3 specimens; sample 1001B/21R/6W/71-75 cm.

\section{Paronaella sp. 2}

(Figure 4C)

Figured specimen. ULVG-7048.

Description. Three-rayed skeleton with rays at various angles. Two rays are positioned at about $180^{\circ}$ to each other and are bigger, while the ray positioned at about $90^{\circ}$ relative to others is smaller. Rays are probably elliptical in cross-section and have broken spines in extremities. Surface rough with nodes on the polygonal pore-frames junctions.

Remarks. This species differs from all other species of the genus recovered in the studied material by the presence of different inter-rays angles.

Material. 4 specimens; sample 1001B/21R/6W/71-75 cm.

Paronaella? sp. 3

(Figure 4B)

Figured specimen. ULVG-7049.

Description. Three-rayed test without bracchiopyle. Rays equal in length, possibly elliptical in cross-section. Test rough without lateral or central spines, and with nodes on the surface. Rays smooth, tending to be slender distally and keep practically the same inter-rays angle.

Remarks. Differs from Paronaella sp. 1 by having rays which tend to be slender distally.

Material. 6 specimens; sample 1001B/21R/6W/71-75 cm.

Family HAGIASTRIDAE Riedel, 1971

Genus Orbiculiforma Pessagno, 1973 emend. Pessagno, 1976 Orbiculiforma persenex Pessagno, 1976

(Figure 4S)

Orbiculiforma persenex Pessagno, 1976, p. 35, pl. 6, figs. 1213.

Orbiculiforma persenex Pessagno. Pessagno, 1977a, p. 944, pl. 5, fig. 6.

Orbiculiforma persenex Pessagno. Urquhart, 1994, p. 1406, fig. 5(8).

Orbiculiforma persenex Pessagno. Packer \& Hart, p. 141, figs. $5 \mathrm{~g}-\mathrm{i}$.

Figured specimen. ULVG-7050

Occurrence. Campanian of Cyprus Island (Urquhart, 1994); Coniacian of Great Valley Sequence, California (Pessagno, 1976, 1977a); Coniacian-Santonian of Bornholm, Denmark (Packer \& Hart, 2005); Coniacian-Turonian of Russia (Vishnevskaya et al., 2006); Santonian-Campanian of the Russian Pacific Margin (Vishnevskaya \& Basov, 2007).

Material. 4 specimens, sample 1001B/21R/6W/71-75 cm.

$$
\begin{gathered}
\text { Orbiculiforma renillaeformis (Campbell \& Clark) } \\
\text { Pessagno, 1976 } \\
\text { (Figure 4L) }
\end{gathered}
$$

Orbiculiforma renillaeformis (Campbell \& Clark) Pessagno. Pessagno, 1976, p. 36, pl. 11, fig. 11.

Figured specimen. ULVG-7051.

Occurrence. Uppermost Campanian to Maastrichtian of Great Valley Sequence, California (Pessagno, 1976).

Material. 9 specimens; sample 1001B/21R/6W/71-75 cm.

$$
\begin{aligned}
& \text { Orbiculiforma sp. } 1 \\
& \text { (Figure } 4 \mathrm{~T} \text { ) }
\end{aligned}
$$

Figured specimen. ULVG-7052.

Description. Test is circular in outline, with or without peripheral spines. Center of test markedly depressed; central cavity flanked by a prominent rim.

Remarks. Differs from Orbiculiforma sp. 2 by possessing a depressed central cavity, and by the flat pattern of the test. Material. 19 specimens; sample 1001B/21R/6W/71-75 cm.

\section{Orbiculiforma sp. 2}

(Figure 4R)

Figured specimen. ULVG-7053.

Description. Test is circular in outline without peripheral 
spines. Center of test markedly depressed and narrow. Central cavity flanked by a rim.

Remarks. Differs from Orbiculiforma sp. 1 by possessing a narrow central cavity, and by the decrease in the height/ width ratio.

Material. 20 specimens; sample 1001B/21R/6W/71-75 cm.

\section{Orbiculiforma? sp. 3 \\ (Figure 4K)}

Figured specimen. ULVG-7054.

Description. Test circular to quadrangular in outline, without visible peripheral spines. Central area well marked.

Remarks. This species differs from all other species assigned to the genus Orbiculiforma in the present study by presenting a well marked central area. All specimens are incomplete.

Material. 5 specimens; sample 1001B/21R/6W/71-75 cm.

Genus Crucella Pessagno, 1971

Crucella aster (Lipman) Nakaseko \& Nishimura, 1981

(Figure 4D)

Crucella aster (Lipman). Packer \& Hart, 2005, p. 141, figs. $5 \mathrm{c}, \mathrm{d}$.

Crucella aster (Lipman). Vishnevskaya \& Alekseev, 2008, p. 1368, fig. $2 \mathrm{~g}$.

Figured specimen. ULVG-7055.

Occurrence. Campanian of Chypre Island (Urquhart, 1994); Coniacian-Santonian of Bornholm, Denmark (Packer \& Hart, 2005); Coniacian-Turonian of Russia (Vishnevskaya et al., 2006); Santonian-Campanian of Kara Crater, Russia (Vishnevskaya \& Alekseev, 2008).

Material. 4 specimens; sample 1001B/21R/6W/71-75 cm.

Crucella? sp.

(Figure 4E)

Figured specimen. ULVG-7056.

Description. Four-rayed hagiastrid, without bracchiopyle. Rays are equal in length, sharply pointed distally and have three longitudinal costae in each face. Rays are sub-circular to elliptical in cross-section. Central area slightly elevated with pores composed of tetragonal pore-frames.

Remarks. Crucella? sp. differs from Crucella aster by the sharply pointed distally rays-shaped and tetragonal poreframes.

Material. 3 specimens; sample 1001B/21R/6W/71-75 cm.

Family SPONGODISCIDAE Haeckel, 1862

Genus Pentinastrum Haeckel, 1882

Pentinastrum subbotinae Lipman, 1960

(Figure 4N)

Pentinastrum subbotinae Lipman. Bragina et al., 1999, p. 496, pl. 2 , fig. 5 .

Figured specimen. ULVG-7057.
Occurrence. Upper Cretaceous of the Russian Plate (Bragina et al, 1999).

Material. 8 specimens; sample 1001B/21R/6W/71-75 cm

Genus Stylodictya Ehrenberg, 1847

Stylodictya? sp.

(Figure 4H)

Figured specimen. ULVG-7058.

Description. Skeleton flat, slightly concave, and with rounded outline (central portion slightly depressed). In upper view presents polygonal pores distributed in concentric layers, with small nodes at pore-frames junctions. Test possesses a small rounded (in cross section) spine merging from the equatorial plane. Some spines are possible broken.

Remarks. Differs from the genus Orbiculiforma by having a conspicuous concentric arrangement of pores, and by having a more flattened pattern of the test without a central cavity very depressed. Although the genus was originally defined for the Eocene-Recent, Vishnevskaya \& Alekseev (2008) recovered specimens from the Santonian-Campanian of Kara Crater-Russia.

Material. 8 specimens; sample 1001B/21R/6W/71-75 cm.

Family ARCHAEOSPONGOPRUNIDAE Pessagno, 1973

Genus Archaeospongoprunum Pessagno, 1973 Archaeospongoprunum sp.

(Figure 4J)

Figured specimen. ULVG-7059.

Description. Test ellipsoidal, spongy, with two polar spines; polar spines broken off, probably tetraradiate in axial section with an arrangement of ridges alternating with grooves.

Remarks. The broken spines make difficult a specific determination.

Material. 2 specimens; sample 1001B/21R/6W/71-75 cm.

\section{SPUMELLARIAINCERTAE SEDIS \\ Spumellaria gen. et sp. indet.}

(Figure 3V)

Figured specimen. ULVG-7060.

Remarks. Large spherical Spumellaria, with well-developed pores and smooth surface.

Material. 6 specimens; sample 1001B/21R/6W/71-75 cm.

\section{Ostracodes}

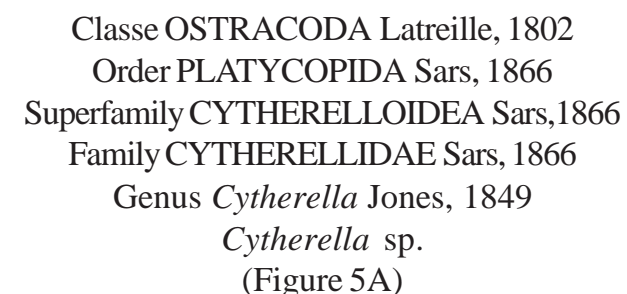

Figured specimen. ULVG-7011. 

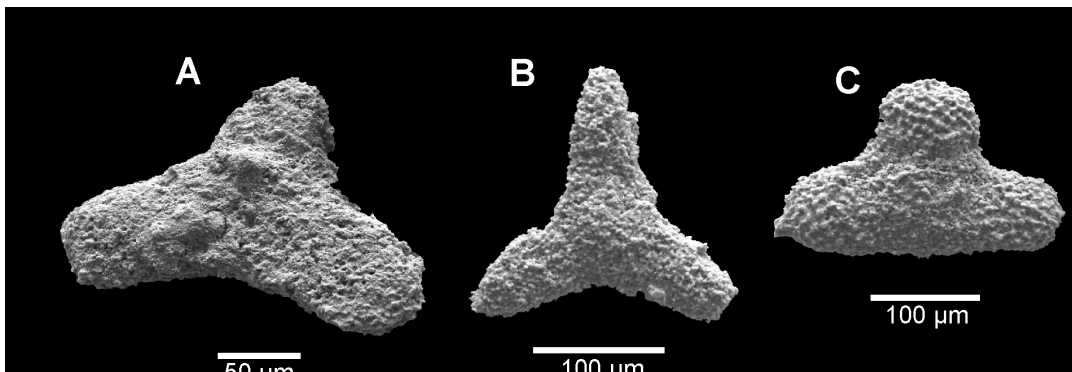

D

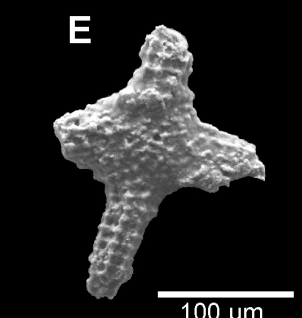

F
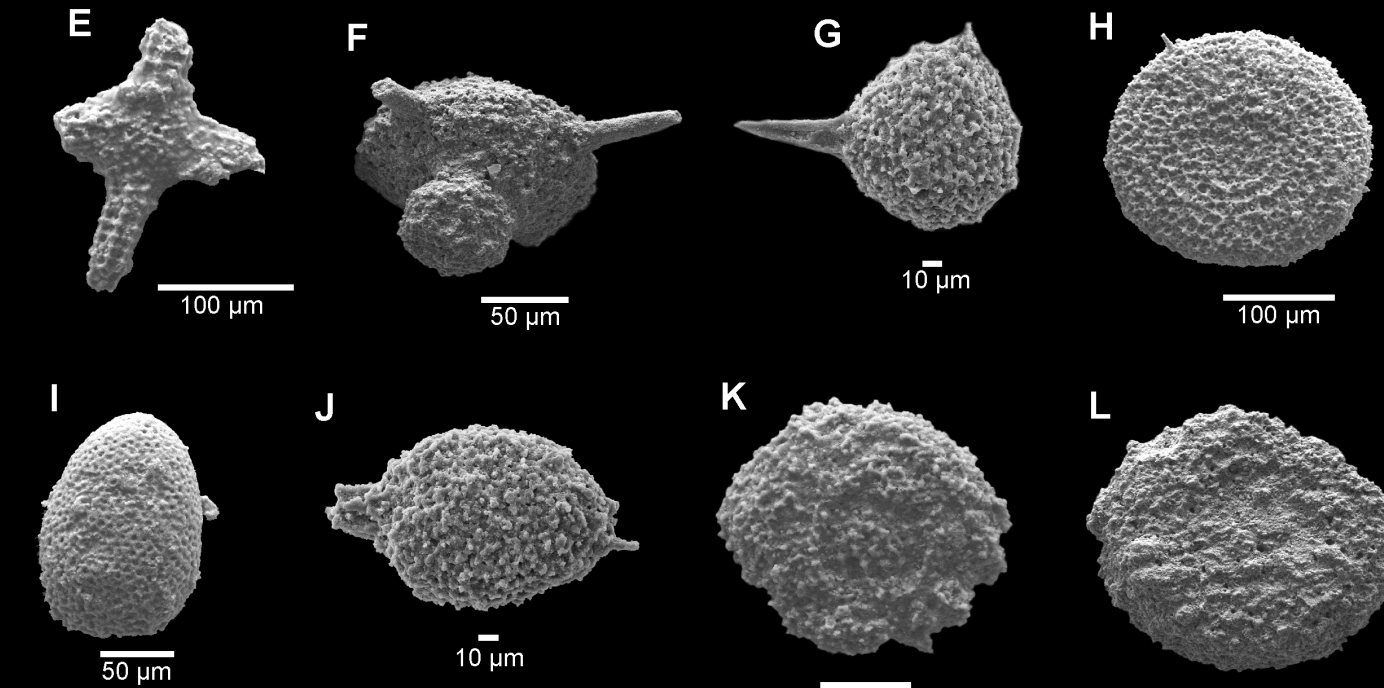

$50 \mu \mathrm{m}$
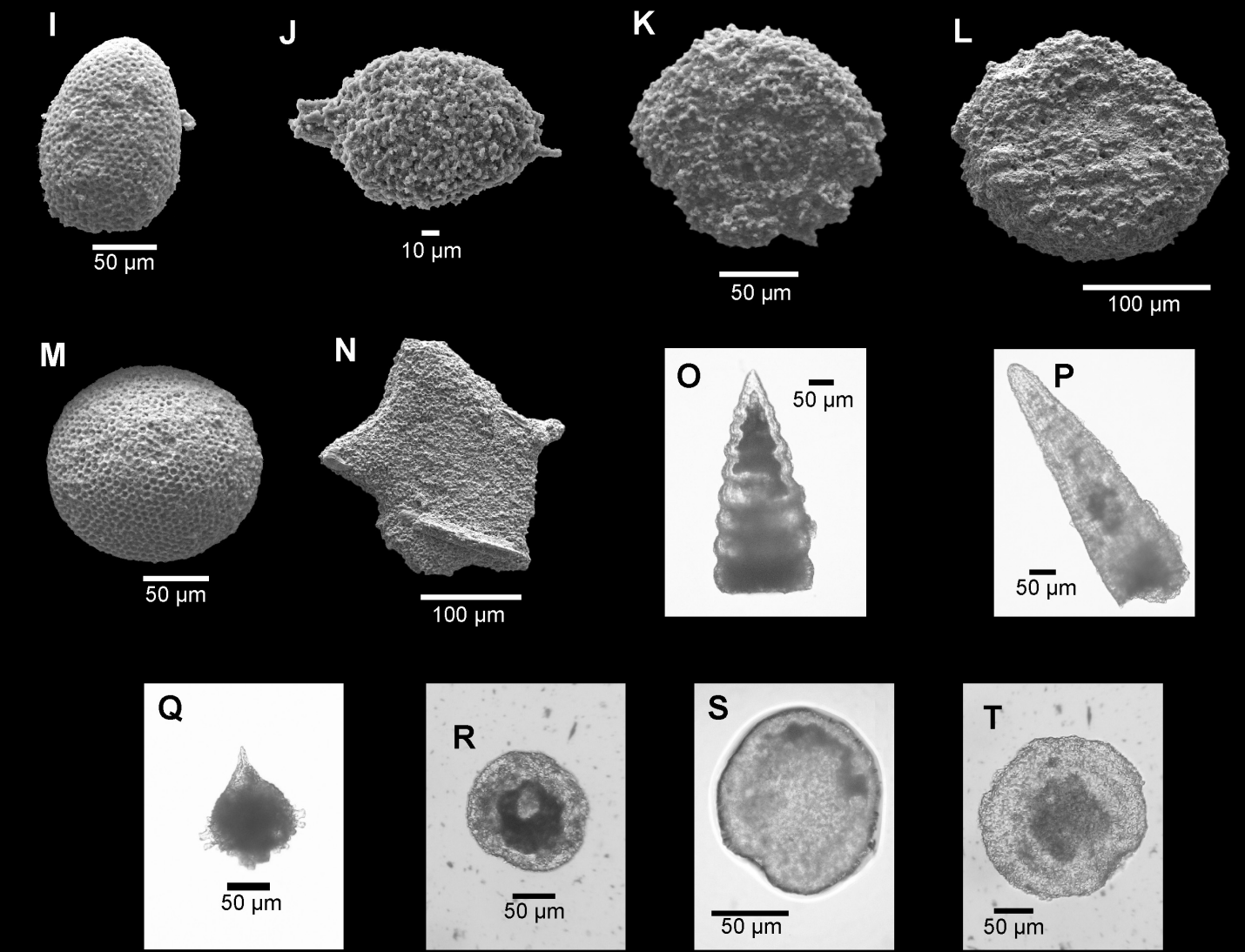

Figure 4. A, Paronaella sp. 1, sample 1001B/21R/6W/71-75 cm. B, Paronaella? sp. 3, sample 1001B/21R/6W/71-75 cm. C, Paronaella sp. 2, sample 1001B/21R/6W/71-75 cm. D, Crucella aster (Lipman) Nakaseko \& Nishimura, sample 1001B/21R/6W/71-75 cm. E, Crucella? sp., sample 1001B/21R/6W/71-75 cm. F, Pseudoaulophacus? sp., sample 1001B/21R/6W/71-75 cm. G, Alievium sp., sample 1001B/21R/6W/ 71-75 cm. H, Stylodictya? sp., sample 1001B/21R/6W/71-75 cm. I, Nassellaria gen. et sp. indet., sample 1001B/21R/6W/71-75 cm. J, Archaeospongoprunum sp., sample 1001B/21R/6W/71-75 cm. K, Orbiculiforma? sp. 3, sample 1001B/21R/6W/71-75 cm. L, Orbiculiforma renillaeformis (Campbell \& Clark) Pessagno, sample 1001B/21R/6W/71-75 cm. M. Actinommidae gen. et sp. indet., sample 1001B/21R/6W/ 71-75 cm. N, Pentinastrum subbotinae Lipman, sample 1001B/21R/6W/71-75 cm. O, Dictyomitra densicostata Pessagno, sample 1001B/ 21R/6W/71-75 cm. P, Archaeodictyomitra regina (Campbell \& Clark) Pessagno, sample 1001B/21R/6W/71-75 cm. Q, Krempelinella sp. cf. K. kronenartiga Empson-Morin, sample 1001B/21R/6W/71-75 cm. R, Orbiculiforma sp. 2, sample 1001B/21R/6W/71-75 cm. S, Orbiculiforma persenex Pessagno, sample 1001B/21R/6W/71-75 cm. T, Orbiculiforma sp. 1, sample 1001B/21R/6W/71-75 cm. Figures O-T are optic micrographs of Radiolaria from Site 1001B. 
Dimensions. $\mathrm{L}=0.58 \mathrm{~mm} ; \mathrm{h}=0.40 \mathrm{~mm} ; \mathrm{w}=0.25 \mathrm{~mm}$.

Locality. Sample 16R/5W/70-75cm.

Age. Danian.

Material. 2 C , $1 \mathrm{LV}$; samples 21R/6W/71-75cm, 18R/4W/70-

$75 \mathrm{~cm}$ and $16 \mathrm{R} / 5 \mathrm{~W} / 70-75 \mathrm{~cm}$.

Range. Maastrichtian-early Danian.

\section{Genus Cytherelloidea Alexander, 1929 \\ Cytherelloidea sp.}

(Figure 5B)

Figured specimen. ULVG-7012.

Dimensions. $\mathrm{L}=0.47 \mathrm{~mm}$; $\mathrm{h}=0.33 \mathrm{~mm}$.

Locality. Sample 20R/2W/77-82 cm.

Age. Maastrichtian.

Material. $1 \mathrm{LV}$; sample 20R/2W/77-82 cm.

Range. Maastrichtian.

Remarks. This species is identified as Cytherelloidea due to the reticulate ornamentation, not usual in Cytherella.

Order PODOCOPIDA Müller, 1894

Suborder BAIRDIOCOPINA Gründel, 1967

Family BAIRDIIDAE Sars, 1888

Genus Bairdoppilata Coryell, Sample \& Jennings, 1935

Bairdoppilata aff. B. southerhamensis Weaver, 1982

(Figure 5C)

aff. Bairdoppilata southerhamensis Weaver, 1982, p. 25-26, pl. 4, figs. 4-6.

Figured specimen. ULVG-7013.

Dimensions. $\mathrm{L}=1.18 \mathrm{~mm} ; \mathrm{h}=0.79 \mathrm{~mm} ; \mathrm{w}=0.58 \mathrm{~mm}$.

Locality. $18 \mathrm{R} / 3 \mathrm{~W} / 72-77 \mathrm{~cm}$.

Age. Danian.

Material. 2C; samples 21R/4W/71-76 cm and 18R/3W/72-77 cm.

Range. Maastrichtian-early Danian.

Remarks. The precise taxonomic position of some bairdiids is under constant discussion. The main difference between Bairdoppilata and Bairdia McCoy, 1844 are the denticles present close to the terminal elements of the hinge of the first. According to the revision of the family Bairdiidae by Maddocks (1969), the genus Bairdia is restricted to the Paleozoic. For this reason, this species is here referred as Bairdoppilata.

\section{Bairdoppilata sp.}

(Figure 5D)

Figured specimen. ULVG-7014.

Dimensions. $\mathrm{L}=1.02 \mathrm{~mm} ; \mathrm{h}=0.69 \mathrm{~mm}$.

Locality. $21 \mathrm{R} / 4 \mathrm{~W} / 71-76 \mathrm{~cm}$.

Age. Maastrichtian.

Material. 2 C, $3 \mathrm{LV}, 4 \mathrm{RV}$; samples 21R/6W/71-75 cm, 21R/4W/ $71-76 \mathrm{~cm}, 21 \mathrm{R} / 1 \mathrm{~W} / 70-75 \mathrm{~cm}, 20 \mathrm{R} / 6 \mathrm{~W} / 73-78 \mathrm{~cm}, 17 \mathrm{R} / 1 \mathrm{~W} / 68-$

$73 \mathrm{~cm}$ and $16 \mathrm{R} / 2 \mathrm{~W} / 71-76 \mathrm{~cm}$.

Range: Maastrichtian-early Danian.
Family SIGILLIDAE Mandelstam, 1960

Genus Cardobairdia Bold, 1960

Cardobairdia sp.

(Figure 5E)

Figured specimen. ULVG-7015.

Dimensions. $\mathrm{L}=0.46 \mathrm{~mm} ; \mathrm{h}=0.22 \mathrm{~mm}$.

Locality. $18 \mathrm{R} / 4 \mathrm{~W} / 70-75 \mathrm{~cm}$.

Age. Danian.

Material. $1 \mathrm{RV}$; sample 18R/4W/70-75 cm.

Range. Early Danian.

Remarks. The genus Cardobairdia is characterized by strong overlap, peculiar central muscle scars and, in most cases, a spine in the posterior margin. Bold (1974) comments that Cardobairdia might possibly be a junior synonym of Sigillium Kuznetsova, 1961. The suprageneric taxonomy of Cardobairdia is still a controverse subject, what explains its allocation in different families. We consider that the classification in the family Sigillidae, according to Dall'Antonia (2003) is more suitable than Saipanettidae as proposed by Bold (1974).

Family TRACHYLEBERIDIDAE Sylvester-Bradley, 1948

Genus Paleoabyssocythere Benson, 1977

Paleoabyssocythere sp.

(Figures 5F, G)

Figured specimen. ULVG-7016.

Dimensions. $\mathrm{L}=0.8 \mathrm{~mm} ; \mathrm{h}=0.51 \mathrm{~mm}$.

Locality. 20R/1W/69-74 cm.

Age. Maastrichtian.

Material. $1 \mathrm{LV}$; sample 20R/1W/69-74 cm.

Range. Maastrichtian.

Remarks. The present specimen was identified as Paleoabyssocythere Benson, 1977 based on both internal and external morphological features. Despite its good preservation the material could not be ascribed to the species described by Benson (1977). It differs from P. cretacea by the absence of the reticulation and the ventrolateral nodosity poorly developed, and from P. cenozoica by the absence of reticulation and the anterodorsal ear less acuminated.

Family KRITHIDAE Mandelstam, 1958

Genus Krithe Brady, Crosskey \& Robertson, 1874

Krithe sp.

(Figure 5H)

Figured specimen. ULVG-7017.

Dimensions. $\mathrm{L}=0.69 \mathrm{~mm} ; \mathrm{h}=0.36 \mathrm{~mm} ; \mathrm{w}=0.29 \mathrm{~mm}$.

Locality. $16 \mathrm{R} / 5 \mathrm{~W} / 70-75 \mathrm{~cm}$.

Age. Danian.

Material. $1 \mathrm{LV}, 1 \mathrm{C}$; samples 16R/5W/70-75 $\mathrm{cm}$ and 16R/2W/ $71-76 \mathrm{~cm}$.

Range: Danian.

Remarks. The main morphological characteristic that allowed the identification of this specimen in Krithe is the presence of the posterior pit, present in all species of the genus. 
Gen. et sp. indet.

(Figure 5I)

Figured specimen. ULVG-7061.

Dimensions. $\mathrm{L}=0.51 \mathrm{~mm} ; \mathrm{h}=0.25 \mathrm{~mm}$.

Locality. Sample 18R/4W/70-75 cm.

Age. Danian.

Material. $1 \mathrm{RV}$; samples 18R/4W/70-75 cm.

Range. Danian.

\section{RESULTS AND DISCUSSION}

\section{Radiolarians}

Studies on Maastrichtian radiolarians are relatively rare. Foreman (1968) described Maastrichtian species, mainly nassellarians, emphasizing internal primary structures. Pessagno (1976) presented a taxonomic and biostratigraphic analysis of radiolarians from the Upper Cretaceous of the Great Valley Sequence, California. According to that author, however, the Maastrichtian interval was not extensively studied in that article. Ling \& Lazarus (1990) and Ling (1991) reported well-preserved Maastrichtian faunas from the Antarctic region of the ODP Leg 113 and Leg 114, respectively. Soloviev et al. (2000) reported the occurrence of Campanian-Maastrichtian Radiolaria from the Olyutor Zone (Southern Koryak upland). Dumitrica \& Hollis (2004) studied Maastrichtian phaeodarian Radiolaria from the DSDP Site 275 near New Zealand. Studies about radiolarian faunas that registered the $\mathrm{K} / \mathrm{Pg}$ transition are also not common, being restricted to the Pacific Ocean and more abundant in the New Zealand region (Keller et al., 1997; Hollis, 1997, 2002; Hollis \& Kimura, 2001; Hollis \& Strong, 2003; Hollis et al., 2003).

In the present study, radiolarians were found in two samples of the ODP Site 1001B (Figure 2), and their occurrences are restricted to Maastrichtian rocks (limestones), where 43 species were identified.

The radiolarian abundance, preservation index (PI), and nassellarians/spumellarians ratio (N/S) were estimated according to Kiessling (1996). In the sample 1001B/21R/6W/ $71-75 \mathrm{~cm}$ the estimated radiolarian abundance is of $1900 \mathrm{rads} /$ $\mathrm{g}$ (radiolarians per gram), with $\mathrm{PI}=3$ and $\mathrm{N} / \mathrm{S}=1.28$, while in the sample $1001 \mathrm{~B} / 20 \mathrm{R} / 5 \mathrm{~W} / 69-73 \mathrm{~cm}$ the estimated abundance

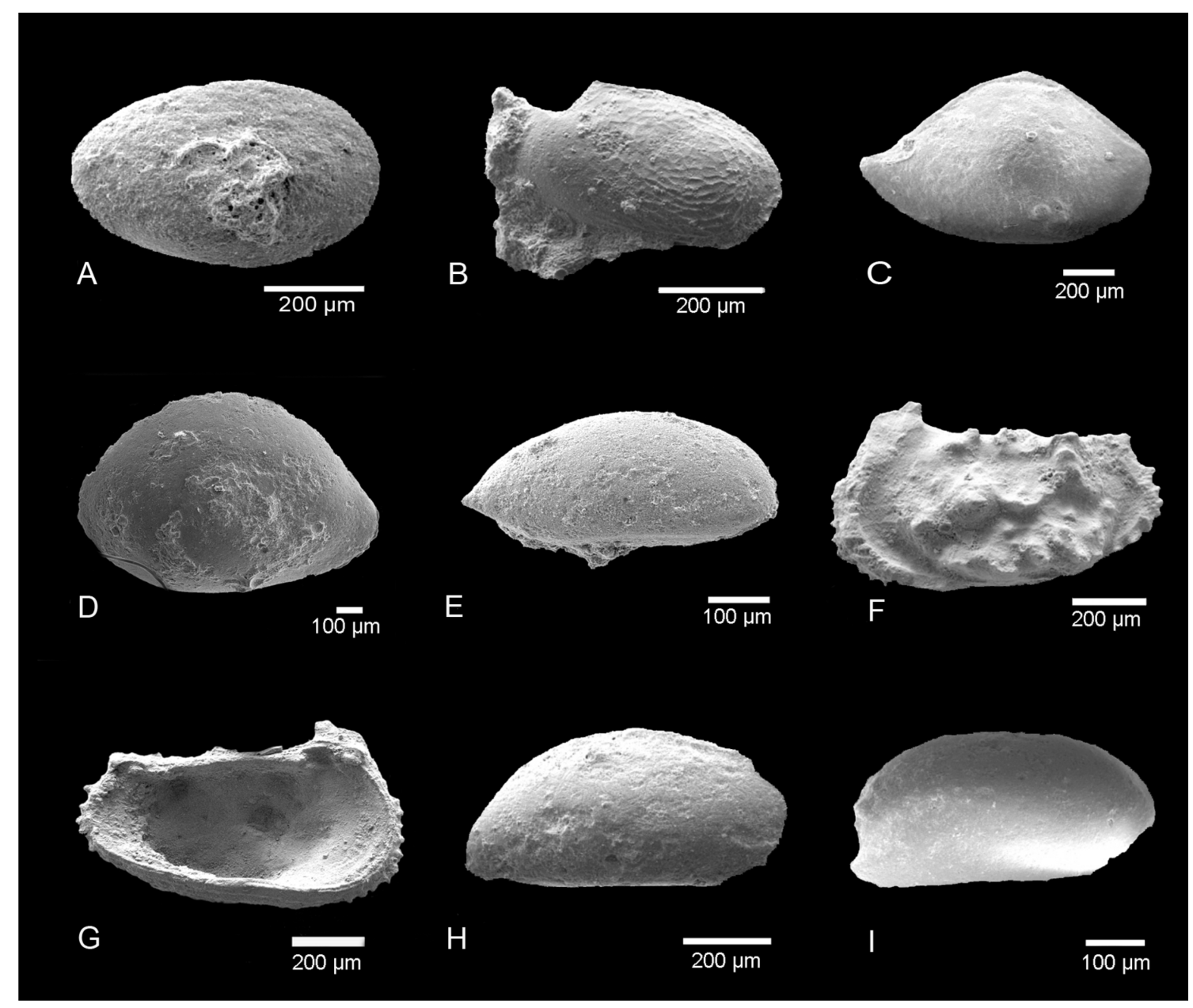

Figure 5. All figures are SEM of ostracodes from Site 1001B. A, Cytherella sp., C right view, sample 16R/5W/70-75 cm. B, Cytherelloidea sp., LV lateral view, sample 20R/2W/77-82 cm. C, Bairdoppilata sp. aff. B. southerhamensis Weaver,1982, C right view, sample 18R/3W/ $72-77 \mathrm{~cm}$. D, Bairdoppilata sp., LV lateral view, sample 21R/4W/71-76 cm. E, Cardobairdia sp., RV lateral view, sample 18R/4W/70-75 cm. F-G, Paleoabyssocythere sp.: F, LV external view; G, LV internal view, sample 20R/1W/69-74 cm. H, Krithe sp., C right view, sample 16R/ $5 \mathrm{~W} / 70-75 \mathrm{~cm}$. I, Gen. et sp. indet., RV lateral view, sample 18R/4W/70-75 cm. 
is of $3000 \mathrm{rads} / \mathrm{g}, \mathrm{PI}=4$ and N/S=4.88. Increases in the relative abundance of nassellarians, as well as in the preservation index were observed in the last sample. The radiolarian fauna recovered from the ODP Site 1001B presents an elevated abundance of the genus Dictyomitra (corresponding approximately to $38 \%$ of the fauna). It contains also typical taxa for the Upper Cretaceous strata, and even species considered index fossils such as Orbiculiforma renillaeformis (Campbell \& Clark) Pessagno.

Pessagno (1976) proposed a biostratigraphic zonation for the Great Valley Sequence, California, in which Maastrichtian strata are attributed to the Orbiculiforma renillaeformis Interval Zone (Pessagno, 1976). The lower limit of this zone is marked by the extinction of the family Phaseliformidae, while the upper limit is marked by the final occurrence of some taxa (see Pessagno, 1976) The absence of Phaseliformids, as well as the co-occurrence of Orbiculiforma renillaeformis (Campbell \& Clark) Pessagno, Archaeodictyomitra regina (Campbell \& Clark) and Dictyomitra multicostata Zittel in the material studied herein suggest a Maastrichtian age for the samples 1001B/21R/6W/ $71-75 \mathrm{~cm}$ and $1001 \mathrm{~B} / 20 \mathrm{R} / 5 \mathrm{~W} / 69-73 \mathrm{~cm}$, including them in the Orbiculiforma renillaeformis Interval Zone (Pessagno, 1976). A Maastrichtian age was previously reported by Sigurdsson et al. (1997), based on nannofossils and foraminifers, to the same interval of the section (Figure 2).

The sparse occurrences of radiolarians in the studied area could be related to occasional intensifications in the oceanic circulation pattern (Blueford, 1988). Those events could have generated increases in the planktonic productivity during the Late Cretaceous (De Wever \& Baudin, 1996). This can be a relevant aspect in the determination of the similarity between radiolarian faunas in the Late Cretaceous, and could be corroborated with future studies.

More studies about Maastrichtian radiolarians in the near future could confirm the stratigraphic range of some Upper Cretaceous taxa, as presented in this study, and contribute to the improvement of the knowledge about the global oceanic circulation in the Upper Cretaceous.

\section{Ostracodes}

The ostracode fauna recorded in the present work shows an uneven distribution along the core. Seventeen out the 29 samples studied were barren for ostracodes and the 19 specimens recovered were identified into seven taxa. They are left in open nomenclature following the scarcity of specimens and the poor preservation of most of them.

Bairdoppilata southerhamensis Weaver described in Cenomanian rocks of England has affinity with the species registered in the Maastrichtian-early Danian in the present study. The difference of age and the scarcity of specimens (two carapaces), however, make the identification of those taxa under the same species questionable.

The deep sea dweller genus Paleoabyssocythere has only two species described so far: P. cretacea and P. cenozoica, both proposed by Benson (1977) in the Cretaceous/Paleogene of São Paulo plateau and Rio Grande rise, South Atlantic.
The single specimen recorded in the present work is somewhat different of both and it is not clear if it is a new species. The only specimen of Cardobairdia sp. (RV) was filled with sediment, preventing a more detailed study and precise identification. Cytherella and Krithe are genera usually smooth and very diversified demanding the study of many specimens and the analysis of internal morphological features for the identification at specific level. The specimens of those two genera in the present study were exclusively carapaces and for that reason, left in open nomenclature.

Despite their scarcity, the ostracodes give some information for the paleoenvironmental characterization of the studied area. In the Cenozoic, the association Paleoabyssocythere-Krithe-Bairdoppilata-Cytherella would fit perfectly in a psychrospheric environment. Although some of those taxa present eurybathic distribution (e.g. Krithe, Cytherella, Bairdoppilata) and their ecologic preferences may have change since the Cretaceous (retrothermal tendencies), it is possible to assume that the depositional environment in the site 1001B was either a bathyal or outer shelf one.

\section{ACKNOWLEDGMENTS}

The authors are indebted to ODP for providing the samples, as well as to the staff of the Laboratório de Micropaleontologia of Universidade do Vale do Rio dos Sinos by all support and helpful discussions. The authors are grateful to Rogério Martins (CENPES/PETROBRAS) for the SEM images; Paulian Dumitrica (Institut de Géologie et Paléontologie) and Bernard Andreu (Université de Toulouse) for the critical revision of the manuscript.

\section{REFERENCES}

Benson, R.H. 1977. The Cenozoic ostracode faunas of the São Paulo plateau and the Rio Grande rise (DSDP Leg 39, sites 356 and 357). In: K. Perch-Nielsen, P.R. Supko, Y.P. Neprochnov, H.B. Zimmerman, F. McCoy, N. Kumar, J. Thiede, E. Bonatti, R. Fodor, A. Boersma, M.G. Dinkelman, R.L. Carlson (eds.) Initial Reports of Deep Sea Drilling Program, Scientific Results 39, Texas A\&M University, p. 869-883.

Blueford, J.R. 1988. Radiolarian evidence: Late Cretaceous through Eocene ocean circulation patterns. In: J.R. Hein \& J. Obradovic (eds.) Siliceous deposits of the Tethys and Pacific regions, Springer-Verlag, p. 19-29.

Bold, W. van den. 1974. Taxonomic status of Cairdobairdia (Bold, 1960) and Abyssocypris n. gen.: two deepwater ostracode genera of the Caribbean Tertiary. Geoscience and Man, 6:65-79.

Bragina, L.G.; Ben'yamovskii, V.N. \& Zastrozhnov, A.S. 1999. The Upper Cretaceous radiolarians, foraminifers, and stratigraphy of the southeastern Russian Plate, the Right-Bank Volga Region near Volgograd. Stratigraphy and Geological Correlation, 7(5):84-92.

Burke, K. 1988. Tectonic evolution of the Caribbean. Annual Review of Earth and Planetary Sciences, 16:201-230.

Campbell, A.S. \& Clark, B.L. 1944. Radiolaria from Upper Cretaceous of middle California. Geological Society of America, Special Paper, 57:1-61. 
Dall'Antonia, B. 2003. Miocene ostracods from the Tremiti islands and Hyblean plateau: biostratigraphy of new and poorly known species. Geobios, 36:27-54.

De Wever, P. \& Baudin F. 1996. Paleogeography of radiolarite and organic-rich deposits in Mesozoic Tethys. International Journal of Earth Sciences, 85:310-326.

De Wever, P.; Dumitrica, P.; Caulet, J.P.; Nigrini, C. \& Caridroit, M. 2001. Radiolarians in the sedimentary record. $1^{\mathrm{a}}$ ed. Amsterdam, Gordon \& Breach Science Publishers, 533 p.

Donnelly, T.W.; Beets, D.J.; Carr, M.J.; Jackson, T.; Klaver, G.T.; Lewis, J.; Maury, R.; Schellenkens, H.; Smith, A.L.; Wadge, G. \& Westercamp, D. 1990. History and tectonic setting of Caribbean magmatism. In: G. Dengo \& J.E. Case (eds.) The Caribbean region. The Geology of North America, Geological Society of America, H, p. 339-374.

Dumitrica P. \& Hollis C.J. 2004. Maastrichtian Challengeriidae (phaeodarian Radiolaria) from deep sea sediments of SW Pacific. Revue de Micropaléontologie, 47:127-134.

Empson-Morin, K.M. 1981. Campanian Radiolaria from DSDP Site 313, mid-Pacific Mountains. Micropaleontology, 27(3):249-292.

Foreman, H.P. 1968. Upper Maestrichtian Radiolaria of California. The Paleontological Association, Special Papers in Paleontology, 3:1-82.

Hollis, C.J. 1997. Cretaceous-Paleocene Radiolaria from eastern Marlborough, New Zealand. Institute of Geological and Nuclear Sciences Monograph, 17:1-152.

Hollis, C.J. 2002. Biostratigraphy and paleoceanographic significance of Paleocene radiolarians from offshore eastern New Zealand. Marine Micropalentology, 46:256-316.

Hollis, C.J. \& Kimura, K. 2001. An unified radiolarian zonation for the Late Cretaceous and Paleocene of Japan. Micropaleontology, 47(3):235-255.

Hollis, C.J. \& Strong, C.P. 2003. Biostratigraphic review of the Cretaceous/Tertiary transition, mid-Waipara River section, North Canterbury, New Zealand. New Zealand Journal of Geology and Geophysics, 46:243-253.

Hollis, C.J.; Strong, C.P.; Rodgers, K.A. \& Rogers, K.M. 2003. Paleoenvironmental changes across the Cretaceous/Tertiary boundary at Flaxbourne River and Woodside Creek, eastern Marlborough, New Zealand. New Zealand Journal of Geology \& Geophysics, 46:177-197.

Keller, G.; Thierry, A.; Hollis, C.; Ordóñes, M.; Zambrano, I.; Jiménez, N.; Stinnesbeck, W.; Aleman, A. \& Hale-Erlich, W. 1997. The Cretaceous-Tertiary boundary event in the Ecuador: reduced biotic effect due to eastern boundary current setting. Marine Micropaleontology, 31:97-133.

Kiessling, W. 1996. Facies characterization of mid-Mesozoic deepwater sediments by quantitative analysis of siliceous microfaunas. Facies, 35:237-274.

Ling, H.Y. 1991. Cretaceous (Maestrichtian) radiolarians: Leg 114. In: P.F. Ciesielski; Y. Kristoffersen; B. Clement; J.P. Blangy; R. Bourrouilh; J.A. Crux; J.M. Fenner; P.N. Froelich; E. Hailwood; D. Hodell; M.E. Katz; H.Y. Ling; J. Mienert; D. Müller; C.J. Mwenifumbo; D.C. Nobes; M. Nocchi; D.A. Warnke \& F. Westall (eds.) Proceedings of the Ocean Drilling Program, Scientific Results 114, Texas A\&M University, p. 317-324.

Ling, H.Y. \& Lazarus, D.B. 1990. Cretaceous Radiolaria from the Weddell Sea: Leg 113 of the ocean drilling Program. In: P.F. Barker; J.P. Kennett; S. O'Connell; S. Berkowitz; W.R. Bryant; L.H. Burckle; P.K. Egeberg; D.K. Fütterer; R.E. Gersonde; X. Golovchenko; N. Hamilton; L. Lawver; D.B. Lazarus; M. Lonsdale; B. Mohr; T. Nagao; E. Schandl; V. Spiess; L.D. Stott;
E. Thomas; K.F.M. Thompson \& S.W. Wise, Jr. (eds.) Proceedings of the Ocean Drilling Program, Scientific Results 133, Texas A\&M University, p. 353-363.

Macleod, N.; Rawson, P.F.; Forey, P.L.; Banner, F.T.; BoudagherFadel, M.K.; Bown, P.R.; Burnett, J.A.; Chambers, P.; Culver, S.; Evans, S.E.; Jeffery, C.; Kaminski, M.A.; Lord, A.R.; Milner, A.C.; Milner, A.R.; Morris, N.; Owen, E.; Rosen, B.R.; Smith, A.B.; Taylor, P.D.; Urquhart, E. \& Young J.R. 1997. The Cretaceous-Tertiary Biotic Transition. Journal of the Geological Society, 154:265-292.

Musavu-Moussavou, B. \& Danelian, T. 2006. The Radiolarian biotic response to Oceanic Anoxic Event 2 in the southern part of the northern proto-Atlantic (Demerara Rise, ODP Leg 207). Revue de Micropaléontologie, 49:141-163.

O’Dogherty, L. 1994. Biochronology and Paleontology of MidCretaceous radiolarians from Northern Apennines (Italy) and betic Cordillera (Spain). Mémoires de Géologie, 21:1-415.

Olfer'ev, A.G.; Beniamovski, V.N.; Vishnevskaya, V.S.; Ivanov, A.V.; Kopaevich, L.F.; Pervushov, E.M.; Sel'tser, V.B.; Tesakova, E.M.; Kharitonov, V.M. \& Shcherbinina, E.A. 2007. Upper Cretaceous deposits in the northwest of Saratov Oblast, Part 1: litho- and biostratigraphic analysis of the Vishnevoe Section. Stratigraphy and Geological Correlation, 15(6):610-655.

Packer, S.R. \& Hart, M.B. 2005. Coniacian-Santonian Radiolaria from the Upper Cretaceous of Bornholm, Denmark: a preliminary investigation. Bulletin of the Geological Society of Denmark, 52:133-149.

Pessagno, Jr. E.A. 1963. Upper Cretaceous Radiolaria from Puerto Rico. Micropaleontology, 9:197-214.

Pessagno, Jr. E.A. 1972a. Cretaceous Radiolaria. Part I: the Phaseliformidae, new family, and other Spongodiscacea from the Upper Creataceous portion of the Great Valley Sequence. Bulletins of American Paleontology, 61(270):269-280.

Pessagno, Jr. E.A., 1972b. Cretaceous Radiolaria. Part II. Pseudoaulophacidae Riedel from the Cretaceous of California and the Blake-Bahama Basin (JOIDES Leg 1). Bulletins of American Paleontology, 61(270):283-314.

Pessagno, Jr. E.A. 1975. Upper Cretaceous radiolaria from DSDP Site 275. In: J.P. Kennett; R.E. Houtz; P.B. Andrews; A.R. Edwards; V.A. Gostin; M. Hajós; M.A. Hampton; D.G. Jenkins; S.V. Margolis; A.T. Ovenshine \& K. Perch-Nielsen (eds.) Initial Reports of the Deep Sea Drilling Project, Scientific Results 29, Texas A\&M University, p. 1011-1029.

Pessagno, Jr. E.A. 1976. Radiolarian zonation and stratigraphy of the Upper Cretaceous portion of the Great Valley sequence, California Coast Ranges. Micropaleontology, Special Publication, 2:1-95.

Pessagno, Jr. E.A. 1977a. Radiolaria in Mesozoic Stratigraphy. In: A.T.S. Ramsay (ed.) Oceanic Micropaleontology, Academic Press, v. 9, p. 913-950.

Pessagno, Jr. E.A. 1977b. Lower Cretaceous radiolarian biostratigraphy of the Great Valley Sequence and Franciscan Complex, California Coast ranges. Cushman Foundation for Foraminiferal Researc, Special Publication, 15:1-87.

Pindell, J.L. \& Barrett, S.F. 1990. Geologic evolution of the Caribbean region: a plate-tectonic perspective. In: G. Dengo \& J.E. Case (eds.) Geology of the North America, The Caribbean Region, Geological Society of America, H, p. 405-432.

Ridley, M. 1996. Evolution. $2^{\mathrm{a}}$ ed. Oxford, Blackwell Science, 719 p. Sanfilippo, A. \& Riedel, W.R. 1985. Cretaceous Radiolaria. In: H.M. Bolli; J.B. Saunders \& K. Perch-Nielsen (eds.) Plankton Stratigraphy, Cambridge University Press, p. 573-630. 
Sigurdsson, H.; Leckie, R.M.; Acton, G.D.; Abrams, L.J.; Bralower, T.J.; Carey, S.N.; Chaisson, W.P.; Cotillon, P.; Cunningham, A.D.; D’Hondt, S.L.; Droxler, A.W.; Galbrun, B.; Gonzalez, J.; Haug, G.; Kameo, K.; King, J.; Lind, I.L.; Louvel, V.; Lyons, T.W.; Murray, R.W.; Mutti, M.; Myers, G.; Pearce, R.B.; Pearson, D.G.; Peterson, L.C. \& Röhl, U. 1997. Proceedings of the Ocean Drilling Program, Scientific Results 165, Texas A\&M University, $865 \mathrm{p}$.

Soloviev, A.V.; Palechek, T.N. \& Ledneva, G.V. 2000. CampanianMaastrichtian deposits in the frontal part of the Olyutor zone (Southern Koryak Upland). Stratigraphy and Geological Correlation, 8(2):187-194.

Urquhart, E. 1994. New data on the ranges of some Cretaceous Tethyan Radiolaria. Comptes Rendus de l'Académie des Sciences, 318(2):1401-1407.

Urquhart, E. \& Banner F. T. 1994. Biostratigraphy of the supraophiolite sediments of the Troodos Massif, Cyprus: the Cretaceous Perapedhi, Kannaviou, Moni and Kathikas formations. Geological Magagazine, 131(4):499-518.

Vishnevskaya, V.S. \& Alekseev, A.S. 2008. First data on age of radiolarian assemblages from sedimentary dikes in suevites of the Kara Impact Structure. Doklady Earth Sciences, 423A(9):1366-1371.

Vishnevskaya, V.S. \& Basov, I.A. 2007. New data on biotic events during the Santonian-Campanian transition: evidence from microplankton fossils of the Russian pacific margin. Doklady Earth Sciences, 417A(9):1299-1303.

Vishnevskaya, V.S.; Basov, I.A. \& Kurilov, D.V. 2006. The first joint find of Coniacian-Santonian radiolarians and planktonic foraminifers in Western Kamchatka. Doklady Earth Sciences, 409(5):701-705.

Weaver, P.P.E. 1982. Ostracoda from the British Lower Chalk and Planus Marl. Palaeontographic Society Monography, 562(135):1-127.

Received in May, 2009; accepted in September, 2009. 